\title{
Hatching Under Brownification: DOC-Mediated Changes in Physical, but Not Chemical Properties of Water Affect Hatching Patterns of Cladocera Resting Eggs
}

Anderson L. Vargas ( $\nabla$ andersonlvferreira@gmail.com )

Universidade Federal do Rio de Janeiro

Jayme M. Santangelo

Universidade Federal Rural do Rio de Janeiro

Reinaldo L. Bozelli

Universidade Federal do Rio de Janeiro

\section{Research Article}

Keywords: organic carbon, zooplankton, resting eggs, diapause, humic substances, brownification

Posted Date: October 14th, 2021

DOl: https://doi.org/10.21203/rs.3.rs-899325/v1

License: (c) (1) This work is licensed under a Creative Commons Attribution 4.0 International License.

Read Full License 


\section{Abstract}

Dissolved organic carbon (DOC) is often related to the brownification of water in continental aquatic systems and to changes in the physiology of zooplankton organisms. Zooplankton resting eggs are particularly sensitive to changes in light and chemical characteristics of water, but the physical and chemical effects associated to DOC on dormant stages have never been tested before. Herein we tested how DOC affects hatching rates and time to hatching of Cladocera (Diaphanosoma birgei) resting eggs. In order to analyze the chemical (i.e. toxic) and physical (i.e. light attenuation) effects of DOC on hatching patterns, resting eggs were exposed to different concentrations of DOC in an experimental design which isolated chemical from physical effects. We observed higher hatching rates and lower time to hatching at intermediate DOC concentrations. DOC effects on hatching mainly relied on light attenuation, while chemical effects were likely of minor importance. We conclude that DOC may change Cladocera emergence patterns mainly through light attenuation in the water column.

\section{Introduction}

Freshwater environments worldwide are subjected to an increase in water color through the process called "brownification". Brownification is an increase in dissolved organic carbon (DOC) concentration mainly caused by changes in precipitation and temperature which increase the input of allochthonous carbon (Evans et al. 2005; Roulet and Moore 2006) and accelerates the decomposition of organic matter (Weyhenmeyer and Karlsson 2009). Natural DOC concentrations in water bodies vary around 1-30 mg/l, but in some cases DOC concentration may reach up to $100 \mathrm{mg} / \mathrm{l}$, and in some rare cases can exceed 300 $\mathrm{mg} / \mathrm{l}$ (Sobek et al. 2007).

About $95 \%$ of DOC in aquatic systems are composed by humic substances (HS), a complex and chemical variable polymer (Ertel and Perdue 1984). HS can affect aquatic ecosystems physically, i.e. by light attenuation (Jones 1992; Ask et al. 2009), and chemically, i.e. through molecule complexation (Steinberg et al. 2003) and toxic effects (Vigneault et al. 2000; Saebelfeld et al. 2017). As a result, the increase in DOC and HS in aquatic systems has been considered an important factor for biodiversity loss (Hedström et al. 2017; Urrutia-Cordero et al. 2017; Arzel et al. 2020). HS may alter the trophic structure of aquatic environments through light attenuation by decreasing primary production (Salonen et al. 1992; Hansson et al. 2013) and by decreasing the detection capacity of visual hunting predators (Santonja et al. 2017). HS may chemically interfere in aquatic systems by serving as an energy source for bacteria and by promoting toxic effects in zooplankton (Jansson et al. 1999; Ask et al. 2009). Due to the complex effects promoted by HS in varying aquatic systems, their effects on aquatic biota can be positive or negative depending on their chemical composition and concentration and on species identity. For example, regarding zooplankton organisms, DOC increments can alter vertical migration patterns (Wêgleñska et al. 1997; Karpowicz and Ejsmont-karabin 2018) and some life history traits (Glover et al. 2005; CarvalhoPereira et al. 2015; Cruz et al. 2016). 
Many zooplankton organisms can produce a resting egg able to survive harsh environmental conditions. Resting eggs usually accumulate in the sediment and create a resting egg bank (Brendonck 1996).

Resting eggs hatch when favorable environmental conditions resume and zooplankton colonize the water column. Thus, resting egg banks contribute to the maintenance and resilience of aquatic systems.

Resting eggs hatching may be affected by a myriad of factors, but the presence of light is considered the main trigger for starting egg development (Pancella and Stross 1963; Vandekerkhove et al. 2005;

Ślusarczyk and Flis 2019).

Although resting eggs are acknowledged to survive under many physical and chemical stressors, some chemical compounds like heavy metals and organic compounds can make resting eggs fail to hatch (Jiang et al. 2007; Aránguiz-Acuña and Serra 2016). The survival of resting eggs may depend on the identity and concentration of stressors, and the ability of eggs to withstand stressors is also taxa dependent (Aránguiz-Acuña et al. 2018). In addition, some compounds do not have direct effects on organisms, but affect the environment so that organisms are affected indirectly (Relyea and Hoverman 2006; Gessner and Tlili 2016), i.e. the triazine can diminish the phytoplankton biomass which reduces the abundance of herbivore zooplankton (Kasai and Hanazato 1995). Although DOC can be toxic for some active zooplankton and promote the "brownification" of aquatic environments, the effects of DOC on hatching patterns have not been evaluated before.

In this study we seek to evaluate the effects of DOC on hatching patterns of Diaphanosoma birgei (Cladocera) resting eggs through changes in the chemical and physical properties of water. We hypothesized that higher DOC concentrations cause chemical stress and at the same time attenuate light intensity in the water. As a consequence, hatching rates decrease and time to first hatching may increase. We encountered a predominant effect of light attenuation over chemical stress in the hatching rates of $D$. birgei resting eggs exposed to DOC concentrations.

\section{Materials And Methods}

\subsection{Resting eggs}

The experiment used resting eggs obtained in sediment samples from an artificial, $>50$ year-old lake located in the city of Seropédica ( $22^{\circ} 45^{\prime} 56^{\prime \prime}$ S, $43^{\circ} 41^{\prime} 28^{\prime \prime}$ W), Rio de Janeiro State, Southeastern Brazil. The water volume in the lake is exclusively maintained by rain and DOC concentrations vary around 12 $\mathrm{mg} / \mathrm{l}$. Sediment was collected in May 2017 with an $8 \mathrm{~cm}$ diameter sediment core. Sediment was kept in the dark under room temperature until the beginning of the experiment ( 2 months later) as described below.

Resting eggs were isolated from the sediment using the sugar flotation method (Onbé, 1978; Vandekerkhove et al., 2004) and separated under a stereomicroscope. A total of 400 healthy-looking resting eggs of the cladoceran Diaphanosoma birgei (Korinek, 1981) were used. Diaphanosoma resting 
eggs are released without ephippia, thus increasing the exposure of the embryo to light. The resting eggs were assigned to one of five treatments immediately after isolation from the sediment.

\subsection{Dissolved organic carbon}

We used water from Atoleiro pond as the source of DOC. Atoleiro is a natural intermittent small pond formed by the semi-permanent rising of the water table in the sandy soil in the Restinga de Jurubatiba National Park (22 $13^{\prime} \mathrm{S}$ and $41^{\circ} 29^{\prime} \mathrm{W}$, Rio de Janeiro State, Brazil). The water of this pond usually contains large amounts of DOC, with more than $90 \%$ of its concentration composed by allochthonous humic substances, mostly derived from organic matter present in the impermeable soil layer (Suhett et al. 2013). Water from this environment was previously used to evaluate the effects of different DOC concentrations on the life history of the cladoceran Moina macrocopa (Suhett et al. 2011). After collection, the water was kept in a dark room to protect the humic DOC from photo-oxidation and filtered shortly before use through GF/F glass-fiber filters $(0.7 \mu \mathrm{m}$ particle retention) to remove solid particles.

The DOC concentration in water was measured using a high temperature catalytic oxidation analyzer (Shimadzu TOC 5050) with Pt catalyst at $680^{\circ} \mathrm{C}$. A sample with phosphoric acid was purged before analyses to remove inorganic carbon. Synthetic air was used as carrier gas in the TOC analyzer. The DOC color measured at $254 \mathrm{~nm}$ wavelength was 0.3452 of absorbance (Shimadzu $1700 \mathrm{UV}$-Vis spectrophotometry). DOC concentration in the pond water was $123 \mathrm{mg} / \mathrm{l}$.

\subsection{Experimental design}

Filtered pond water was diluted with mineral water (Minalba ${ }^{\circledR}$, Brazil) to obtain target concentrations of $50 \mathrm{mg} / \mathrm{l}$ and $100 \mathrm{mg} / \mathrm{I} \mathrm{DOC}$. The $\mathrm{pH}$ of all solutions was adjusted to 7.0 to avoid confounding effects of $\mathrm{pH}$ variability. Flasks of different volumes were used to isolate resting eggs from chemical (i.e. toxic) and physical (i.e. light attenuation) effects of DOC (Fig. 1). Small flasks (50 mL volume) were used to expose resting eggs to direct effects of DOC (chemical effects and physical effects) by incubating resting eggs in water containing the target DOC concentrations, while big flasks ( $500 \mathrm{~mL}$ volume) surrounding small flasks were used to expose resting eggs to physical effects of DOC. Thus, a small flask was kept inside a big flask in each replicate without the exchange of water between them. The small flasks were fixed in a glass structure at the bottom of the big flasks during the experiment (Fig. 1). The experiment design was composed of five treatments allowing to separate chemical from physical effects of DOC: (A) control treatment with $0 \mathrm{mg} / \mathrm{L} \mathrm{DOC} \mathrm{(mineral} \mathrm{water)} \mathrm{in} \mathrm{both} \mathrm{flasks;} \mathrm{(B} \mathrm{and} \mathrm{D)} \mathrm{water} \mathrm{with} 50 \mathrm{mg} / \mathrm{L} \mathrm{or} 100 \mathrm{mg} / \mathrm{l}$ of DOC in both flasks, respectively. These treatments simultaneously evaluated both chemical and physical effects of DOC on hatching ("chemical + physical effect"); ( $C$ and $E$ ) mineral water in the small flask and water with $50 \mathrm{mg} / \mathrm{l}$ or $100 \mathrm{mg} / \mathrm{I} \mathrm{DOC}$ in the big flask, respectively (Fig. 1). These treatments evaluated indirect effects of DOC on hatching ("physical" effect) since resting eggs had no direct contact with DOC. Each replicate received 10 resting eggs from $D$. birgei and each treatment had 4 replicates, resulting in 20 experimental units. All flasks were kept at $22^{\circ} \mathrm{C}$ under a $12: 12 \mathrm{~h}$-light/dark cycle in a chamber. The small flasks were observed under a stereoscopic microscope every other day and hatchlings were quantified 
and removed. The experiment lasted 20 days and the last hatchling was observed 12 days after starting the experiment.

Treatments with DOC in small flasks and mineral water in big flasks were not used because light attenuation would occur inside the small flasks, so it was not possible to experimentally evaluate the chemical effects of DOC only. However, the chemical effects of DOC were inferred by comparing "chemical + physical" effects (treatments B and D) and "physical" effect treatments ( $C$ and $E$ ) under the same DOC concentration. If differences were observed, then we could assume it was due to chemical effects, because all treatments were under the same influence of physical effects.

\subsection{Data analysis}

We used generalized linear models (GLM) with a quasi-poisson model and log link function to evaluate the "chemical + physical" and the "physical" effects of DOC in two response variables: hatching numbers and time for first hatching. First, two independent models were used to evaluate the "chemical + physical" and the "physical" effects of DOC by comparing treatments A, B and D, and treatments A, C and E, respectively (Fig. 1). Pairwise comparisons were performed between pairs of treatments when significant effects were observed. Additionally, treatments with the same DOC concentrations (50 or $100 \mathrm{mg} / \mathrm{l}$ ) were compared to evaluate possible chemical effects of DOC (treatments $B \times D$ and $C \times E$ ). If these pair of treatments did not differ, then we assumed DOC had no chemical effects on hatching patterns. The significance of the models was assessed using likelihood ratio tests with quasi F-test. A bootstrap procedure resampling (499 replicates) was previously performed to compare the first hatching time, since some replicates had no hatching. This procedure was necessary to balance all factor levels (Warton et al. 2016).

All analyses were performed using R 4.0 (R development core team 2020) using the vegan package for GLM analyses and emmeans package for pairwise post hoc tests. Graphs were constructed in the ggplot2 package.

\section{Results}

The first hatchlings were observed on the 2 nd day after starting the experiment, and no more hatchlings were observed after 12 days (Fig. 2). Hatchling numbers in the treatments varied from $2.25 \pm 0.47$ to 0.25 \pm 0.25 in "physical" 50 and $100 \mathrm{mg} / \mathrm{l} \mathrm{DOC}$ concentration treatments, respectively. No difference in hatchling numbers was observed when comparing the "chemical + physical" effects of $D O C$ ( $p=0.45, F=$ 0.86 ; treatments $A, B$ and $D$ ), while comparing "physical" effects the difference in treatments was significant $(p=0.04, F=4.57$; treatments $A, C$ and $E)$. Post hoc tests showed that treatments 50 and 100 $\mathrm{mg} / \mathrm{I} \mathrm{DOC}$ differed ( $p=0.02$; treatments $C$ and $E$ ). and hatching was more than $150 \%$ less in $100 \mathrm{mg} / \mathrm{l}$ DOC treatment.

When comparing treatments with the same DOC concentration, no difference was found between "physical" and "chemical + physical" treatments with $50 \mathrm{mg} / \mathrm{l} \mathrm{DOC}(p=0.78, F=0.08$, treatments B and 
C). Similarly, no difference was observed between "physical" and "chemical + physical" treatments with $100 \mathrm{mg} / \mathrm{I} \mathrm{DOC}(\mathrm{p}=0.30, F=1.28$, treatments $\mathrm{D}$ and $E)$. Combined, these results suggest that physical effects of DOC are more important than chemical effects to determine hatching rates.

The time to first hatching varied from 2 to 12 days in "physical" 50 and $100 \mathrm{mg} / \mathrm{l} \mathrm{DOC}$ concentration treatments, respectively. Significant differences were observed in "chemical + physical" $(p<0.01, F=3.37$; treatments $A, B$ and $D)$ and "physical" effects of $D O C(p<0.001, F=5.14$; treatments $A, C$ and $E)$. The time to first hatching in "chemical + physical" treatments was shorter in 50 than control, which was shorter than $100 \mathrm{mg} / \mathrm{I} \mathrm{DOC}$. Compared to control, time to first hatching was $66 \%$ lesser in $50 \mathrm{mg} / \mathrm{l} \mathrm{DOC}$ and $100 \%$ higher in $100 \mathrm{mg} / \mathrm{I}$ DOC. Similarly, time to first hatching in "physical" effects treatments was shorter in 50 than control, which was shorter than $100 \mathrm{mg} / \mathrm{I} \mathrm{DOC}$. Compared to control, time to first hatching was $66 \%$ lesser in $50 \mathrm{mg} / \mathrm{I} \mathrm{DOC}$ and 66\% higher in $100 \mathrm{mg} / \mathrm{l} \mathrm{DOC.}$

Finally, no differences were observed in $50(p=1.00$, treatments $B$ and $C)$ or $100 \mathrm{mg} / \mathrm{l} D O C(p=0.08, F=$ 3.18 , treatments $D$ and $E$ ) when comparing time to first hatching in treatments with the same DOC concentration.

\section{Discussion}

This study assessed how DOC affects the hatching patterns of resting eggs of a common tropical cladoceran, Diaphanosoma birgei. We observed that the joint exposure of resting eggs to chemical and physical effects of DOC (treatments A, B and D) did not affect the hatchling numbers, but affected the time to first hatching in opposing directions depending on DOC concentration, i.e. $50 \mathrm{mg} / \mathrm{l} \mathrm{DOC}$ decreased the time to first hatching, while $100 \mathrm{mg} / \mathrm{I}$ DOC increased it. Similarly, we observed that physical effects of DOC affected hatchling numbers and time to hatching in opposing directions (treatments $A, C$ and $E$ ), since treatments with $50 \mathrm{mg} / \mathrm{I} \mathrm{DOC}$ displayed higher hatchling numbers and lower time to hatching, while the opposite pattern was observed in $100 \mathrm{mg} / \mathrm{l}$ treatments. Because comparisons of treatments with the same DOC concentration (treatments $B \times C$, and $D \times E$ ) did not differ in any response variable, we conclude that chemical effects of DOC have weak to no effects on hatching patterns. As such, physical effects of DOC, especially through light attenuation under increasing DOC concentrations, seems to be the main cause of $\mathrm{DOC}$ changing hatching patterns of resting eggs. These findings partially corroborate our hypothesis that increasing DOC reduces hatchling numbers and increases the time to hatching, because responses of resting eggs to increasing DOC were non-linear and responded solely to light attenuation.

Light attenuation by DOC is mainly caused by the ability of humic substance carbon chains to reflect light (Danilov and Ekelund 2001; Huovinen et al. 2003; Faithfull et al. 2015). Light and temperature are largely acknowledged as the main triggers for hatching zooplankton resting eggs (Vandekerkhove et al., 2005). The light effect on hatching was first acknowledged in temperate systems, where abrupt changes in the photoperiod over seasons signalize changes in food abundance and other environmental conditions (Taghavi et al. 2013; Stewart et al. 2017). The photoperiod in tropical ecosystems where the 
resting eggs of this study originated does not drastically change over seasons, but light intensity may still vary as water depth and turbidity changes, thus potentially influencing hatching patterns. More recently, light intensity has been pointed out as an additional important factor for terminating diapause, as Daphnia magna resting eggs exposed to the same photoperiod under different light intensities showed higher hatching rates under higher light intensities (Slusarczyk and Flis, 2019). Our results are thus in agreement with earlier studies showing that light affects hatching patterns, but contrast with the results from Slusarczyk and Flis (2019) as intermediate light intensities promoted higher hatching rates in our experiment. Thus, we suggest for the first time that DOC may affect hatching patterns of resting eggs by attenuating light intensity.

Contrary to our expectations, DOC had no effects on hatching patterns when in direct contact with resting eggs. DOC is acknowledged to directly affect several life history parameters of cladocerans, as HS may be taken up by organisms and interact with biochemical constituents and signaling pathways (Steinberg et al., 2006; Suhett et al., 2011; Nova et al., 2018). Additionally, DOC may dye the body surface of cladocerans turning them darker. If DOC also dyes the external layer of resting eggs, then the amount of light reaching resting eggs will diminish and hatching patterns may change. It is possible that the exposure time of resting eggs to chemical effects of DOC in our experiment was not long enough to allow DOC to dye the surface of resting eggs. However, this could be tested by exposing resting eggs to DOC under inhibiting conditions for hatching for a longer time, and then testing for changes in surface pigmentation and hatching patterns of resting eggs.

The absence of chemical DOC effects on hatching patterns may be a consequence of the ability of resting eggs to tolerate high concentrations of chemical stressors, mainly due to the resistance and low permeability of resting eggs' superficial layers. Indeed, earlier studies testing the effects of salinity, heavy metals and organic compounds other than DOC have shown that resting eggs can resist the chemical stress (Yan et al., 2004; Jiang et al., 2007; Aránguiz-Acuña; Serra, 2016) and hatch when favorable conditions resume. However, earlier studies that sought to evaluate the chemical substances that affect hatching patterns usually tested substances which are highly toxic and under unrealistic high concentrations (Hanazato 1998, 2001). The toxic potential of DOC is low in comparison with most other compounds currently tested, as it is naturally found in different concentrations ranging from low levels up to $300 \mathrm{mg} / \mathrm{l}$ (Blodau et al. 2004; Sobek et al. 2007).

Interestingly, DOC effects on hatching patterns were non-linear, as intermediate concentrations $(50 \mathrm{mg} / \mathrm{L}$ DOC) determined higher hatchling numbers and lower time to hatching. This finding agrees with earlier studies on DOC effects on active cladocerans. Overall, intermediate DOC concentrations are more beneficial than extreme values (Suhett et al. 2011). For active organisms, it has been suggested that intermediate DOC concentrations benefit organisms by inducing genes related to stress responses (Steinberg et al. 2010). The higher hatching in intermediate concentrations of DOC can possibly occur because light attenuation promotes an optimal light stimulus in eggs. Moreover, the toxic effect of DOC would only occur in high concentrations, with an intermediate concentration to be inert or little toxic. 
Thus, the light attenuation process can be a dominant factor in resurgence processes mediated by DOC mainly in intermediate concentrations.

DOC of any source with high HS concentration attenuates light intensity. Factors other than DOC in natural systems which can affect light intensity in bottom sediments where resting eggs accumulate are depth, inorganic turbidity and algal biomass (Scheffer, 1999; Henley et al., 2000; Donohue and Garcia Molinos, 2009). Resting eggs deposited in the sediment receive less light as those factors increase, but DOC is commonly acknowledged as the main factor of light attenuation in aquatic systems (Morris et al., 1995; Karlsson et al., 2009).

Changes in DOC concentrations can affect the reestablishment of zooplankton populations by changing the hatching success and time to hatching. Resting egg banks are the main contributors for community resilience after disturbances in natural environments (Hairston et al., 2000; Brendonck and De Meester, 2003). DOC effects can change the relative abundances of species which are more sensitive to light and create a numeric advantage in individuals able to reproduce fast in the water column.

This is the first study assessing how DOC affects zooplankton resting eggs and provided an effective separation of physical and chemical effects of DOC. Our study suggests that DOC mainly affects hatching patterns through light attenuation, and this effect can influence the number of hatchlings and the time to hatching. The increase of DOC in freshwater systems worldwide (water brownification) will affect hatching patterns and may have important ecological consequences in the future. Moreover, the effects of DOC in resting eggs of varying taxa and at the community level remains to be evaluated, as species may differ in their responses to varying DOC concentrations.

\section{Declarations}

All participants of that article consent to participate and publish this manuscript. We declare that we do not have any conflict of interests in the preparation of this manuscript. The main idea, scientific experiment and statistical analysis were performed by A.L.V. with supervision of the other authors. J.M.S. helped in the material collection, analysis supervision and writing the text. R.L.B. helped in the material collection, chemical and biologicals analyses and text supervision. This study was supported by research grants from CNPq, finance code: 133418/2017-0

\section{Acknowledgment}

This study was supported by research grants from CNPq. A.L.V is grateful to CAPES and CNPq and Institutions for master's degree scholarships. We are also indebted to the staff of the Núcleo de Desenvolvimento Sócio-Ambiental de Macaé (NUPEM/UFRJ).

\section{Availability of data and materials}

Not applicable. 


\section{Ethical approval}

Not applicable.

\section{Consent to participate}

All participants of that article consent to participate.

\section{Consent to publish}

All participants of that article consent to publish this manuscript.

\section{Authors contributions}

The main idea, scientific experiment and statistical analysis were performed by A.L.V. with supervision of the other authors. J.M.S. helped in the material collection, analysis supervision and writing the text. R.L.B. helped in the material collection, chemical and biologicals analyses and text supervision.

\section{Funding}

This study was supported by research grants from CNPq, finance code: 133418/2017-0

\section{Competing interests}

We declare that we do not have any conflict of interests in the preparation of this manuscript.

\section{Availability of data and materials}

Not applicable.

\section{References}

1. Aránguiz-Acuña A, Pérez-Portilla P, De la Fuente A, Fontaneto D (2018) Life-history strategies in zooplankton promote coexistence of competitors in extreme environments with high metal content. Sci Rep 8:1-10. https://doi.org/10.1038/s41598-018-29487-3

2. Aránguiz-Acuña A, Serra M (2016) Diapause as escape strategy to exposure to toxicants: response of Brachionus calyciforus to arsenic. Ecotoxicology 25:708-719. https://doi.org/10.1007/s10646-0161629-7

3. Arzel C, Nummi P, Arvola L, et al (2020) Invertebrates are declining in boreal aquatic habitat: The effect of brownification? Sci Total Environ 724:. https://doi.org/10.1016/j.scitotenv.2020.138199

4. Ask J, Karlsson J, Persson L, et al (2009) Terrestrial organic matter and light penetration: Effects on bacterial and primary production in lakes. Limnol Oceanogr 54:2034-2040.

https://doi.org/10.4319/lo.2009.54.6.2034 
5. Blodau C, Basiliko N, Moore TR (2004) Carbon turnover in peatland mesocosms exposed to different water table levels. Biogeochemistry 67:331-351. https://doi.org/10.1023/B:BIOG.0000015788.30164.e2

6. Brendonck L (1996) Diapause, quiescence, hatching requirements: what we can learn from large freshwater branchiopods (Crustacea: Branchiopoda: Anostraca, Notostraca, Conchostraca). Hydrobiologia 320:85-97. https://doi.org/10.1007/BF00016809

7. Brendonck L, De Meester L (2003) Egg banks in freshwater zooplankton: Evolutionary and ecological archives in the sediment. Hydrobiologia 491:65-84. https://doi.org/10.1023/A:1024454905119

8. Carvalho-Pereira TS de A de, Santos T de S, Pestana EMS, et al (2015) Natural humic substances effects on the life history traits of Latonopsis australis SARS (1888) (Cladocera - Crustacea). Chemosphere 120:165-170. https://doi.org/10.1016/j.chemosphere.2014.06.025

9. Cruz LC, Rietzler AC, Dumont HJ (2016) Superior life history traits of Micromoina arboricola in a humic over a non-humic environment. Limnologica 56:1-5. https://doi.org/10.1016/j.limno.2015.11.002

10. Danilov RA, Ekelund NGA (2001) Effects of solar radiation, humic substances and nutrients on phytoplankton biomass and distribution in Lake Solumsjö, Sweden. Hydrobiologia 444:203-212. https://doi.org/10.1023/A:1017535830980

11. Donohue I, Garcia Molinos J (2009) Impacts of increased sediment loads on the ecology of lakes. Biol Rev 84:517-531. https://doi.org/10.1111/j.1469-185X.2009.00081.x

12. Ertel J, Perdue E (1984) Lignin Signature of Aquatic Humic Substances. Science 223:485-487. https://doi.org/10.1126/science.223.4635.485

13. Evans CD, Monteith DT, Cooper DM (2005) Long-term increases in surface water dissolved organic carbon: Observations, possible causes and environmental impacts. Environ Pollut 137:55-71. https://doi.org/10.1016/j.envpol.2004.12.031

14. Faithfull CL, Mathisen P, Wenzel A, et al (2015) Food web efficiency differs between humic and clear water lake communities in response to nutrients and light. Oecologia 177:823-835. https://doi.org/10.1007/s00442-014-3132-2

15. Gessner MO, Tlili A (2016) Fostering integration of freshwater ecology with ecotoxicology. Freshw Biol 61:1991-2001. https://doi.org/10.1111/fwb.12852

16. Glover CN, Pane EF, Wood CM (2005) Humic substances influence sodium metabolism in the freshwater crustacean Daphnia magna. Physiol Biochem Zool 78:405-416. https://doi.org/10.1086/430036

17. Hairston NG, Hansen AM, Schaffner WR (2000) The effect of diapause emergence on the seasonal dynamics of a zooplankton assemblage. Freshw Biol 45:133-145. https://doi.org/10.1046/j.13652427.2000.00386.x

18. Hanazato T (2001) Pesticide effects on freshwater zooplankton: An ecological perspective. Environ Pollut 112:1-10. https://doi.org/10.1016/S0269-7491(00)00110-X 
19. Hanazato T (1998) Response of a zooplankton community to insecticide application in experimental ponds: A review and the implications of the effects of chemicals on the structure and functioning of freshwater communities. Environ Pollut 101:361-373. https://doi.org/10.1016/S02697491(98)00053-0

20. Hansson LA, Nicolle A, Granéli W, et al (2013) Food-chain length alters community responses to global change in aquatic systems. Nat Clim Chang 3:228-233. https://doi.org/10.1038/nclimate1689

21. Hedström P, Bystedt D, Karlsson J, et al (2017) Brownification increases winter mortality in fish. Oecologia 183:587-595. https://doi.org/10.1007/s00442-016-3779-y

22. Henley WF, Patterson MA, Neves RJ, Dennis Lemly A (2000) Effects of Sedimentation and Turbidity on Lotic Food Webs: A Concise Review for Natural Resource Managers. Rev Fish Sci 8:125-139. https://doi.org/10.1080/10641260091129198

23. Huovinen PS, Penttilä H, Soimasuo MR (2003) Spectral attenuation of solar ultraviolet radiation in humic lakes in Central Finland. Chemosphere 51:205-214. https://doi.org/10.1016/S00456535(02)00634-3

24. Jansson $M$, Bergstrom AK, Blomqvist $P$, et al (1999) Impact of allochthonous organic carbon on microbial food web carbon dynamics and structure in Lake Ortrasket. Arch Fur Hydrobiol 144:409428. https://doi.org/10.1127/archiv-hydrobiol/144/1999/409

25. Jiang X Dong, Wang G Zhong, LI S Jing, HE J Feng (2007a) Heavy metal exposure reduces hatching success of Acartia pacifica resting eggs in the sediment. J Environ Sci 19:733-737. https://doi.org/10.1016/S1001-0742(07)60122-3

26. Jones R (1992) Jones, R. (1992). The influence of humic substances on lacustrine planktonic food chains. Hydrobiologia, 73-91. Hydrobiologia 1:73-91

27. Karlsson J, Byström P, Ask J, et al (2009) Light limitation of nutrient-poor lake ecosystems. Nature 460:506-509. https://doi.org/10.1038/nature08179

28. Karpowicz M, Ejsmont-karabin J (2018) Influence of environmental factors on vertical distribution of zooplankton communities in humic lakes. Ann Limnol - Int J Limnol 58:17. https://doi.org/10.1051/limn/2018004

29. Kasai F, Hanazato T (1995) Effects of the triazine herbicide, simetryn, on freshwater plankton communities in experimental ponds. Environ Pollut 89:197-202. https://doi.org/0269-7491/95 $\$ 09.50+0.00$

30. Morris DP, Zagarese $\mathrm{H}$, Williamson $\mathrm{CE}$, et al (1995) The attenuation of solar UV radiation in lakes and the role of dissolved organic carbon. Limnol Oceanogr 40:1381-1391. https://doi.org/10.4319/lo.1995.40.8.1381

31. Nova CC, Bozelli RL, Spitzy A, Müller-Navarra D (2018) Living in a browning environment: Effects on Daphnia's growth and fatty acid pattern. Limnol Oceanogr 1-14. https://doi.org/10.1002/Ino.11016

32. Onbé T (1978) Sugar flotation method for sorting the resting eggs of marine cladocerans and copepods from the sea-bottom sediment. Bull. Japanese Soc. Sci. Fish. 
44:1411.https://doi.org/10.2331/suisan.44.1411

33. Pancella JR, Stross RG (1963) Light induced hatching of Daphnia resting eggs. Chesap Sci 4:135140. https://doi.org/10.2307/1350746

34. Relyea R, Hoverman J (2006) Assessing the ecology in ecotoxicology: A review and synthesis in freshwater systems. Ecol Lett 9:1157-1171. https://doi.org/10.1111/j.1461-0248.2006.00966.x

35. Roulet N, Moore TR (2006) Browning the waters. Nature 444:283-284. https://doi.org/10.1038/444283a

36. Saebelfeld M, Minguez L, Griebel J, et al (2017) Humic dissolved organic carbon drives oxidative stress and severe fitness impairments in Daphnia. Aquat Toxicol 182:31-38. https://doi.org/10.1016/j.aquatox.2016.11.006

37. Salonen K, Kankaala P, Tulonen T, et al (1992) Planktonic food chains of a highly humic lake - II. A mesocosm experiment in summer during dominance of heterotrophic processes. Hydrobiologia 229:143-157. https://doi.org/10.1007/BF00006997

38. Santonja M, Minguez L, Gessner MO, Sperfeld E (2017) Predator-prey interactions in a changing world: humic stress disrupts predator threat evasion in copepods. Oecologia 183:887-898. https://doi.org/10.1007/s00442-016-3801-4

39. Scheffer M (1999) The effect of aquatic vegetation on turbidity; how important are the filter feeders? Hydrobiologia 408-409:307-316. https://doi.org/10.1007/978-94-017-2986-4_34

40. Ślusarczyk M, Flis S (2019) Light quantity, not photoperiod terminates diapause in the crustacean Daphnia. Limnol Oceanogr 64:124-130. https://doi.org/10.1002/Ino.11023

41. Sobek S, Tranvik LJ, Prairie YT, et al (2007) Patterns and regulation of dissolved organic carbon: An analysis of 7,500 widely distributed lakes. Limnol Oceanogr 52:1208-1219. https://doi.org/10.4319/lo.2007.52.3.1208

42. Steinberg CEW, Kamara S, Prokhotskaya VY, et al (2006) Dissolved humic substances - Ecological driving forces from the individual to the ecosystem level? Freshw Biol 51:1189-1210. https://doi.org/10.1111/j.1365-2427.2006.01571.x

43. Steinberg CEW, Ouerghemmi N, Herrmann S, et al (2010) Stress by poor food quality and exposure to humic substances: Daphnia magna responds with oxidative stress, lifespan extension, but reduced offspring numbers. Hydrobiologia 652:223-236. https://doi.org/10.1007/s10750-010-0334-4

44. Steinberg CEW, Paul A, Pflugmacher S, et al (2003) Pure humic substances have the potential to act as xenobiotic chemicals - A review. Fresenius Environ Bull 12:391-401

45. Stewart SD, Hamilton DP, Baisden WT, et al (2017) Variable littoral-pelagic coupling as a food-web response to seasonal changes in pelagic primary production. Freshw Biol 62:2008-2025. https://doi.org/10.1111/fwb.13046

46. Suhett AL, Amado AM, Meirelles-Pereira F, et al (2013) Origin, concentration, availability and fate of dissolved organic carbon in coastal lagoons of the Rio de Janeiro State. Acta Limnol Bras 25:326340. https://doi.org/10.1590/s2179-975x2013000300011 
47. Suhett AL, Steinberg CEW, Santangelo JM, et al (2011) Natural dissolved humic substances increase the lifespan and promote transgenerational resistance to salt stress in the cladoceran Moina macrocopa. Environ Sci Pollut Res 18:1004-1014. https://doi.org/10.1007/s11356-011-0455-y

48. Taghavi D, Farhadian O, Soofiani NM, Keivany Y (2013) Effects of different light/dark regimes and algal food on growth, fecundity, ephippial induction and molting of freshwater cladoceran, Ceriodaphnia quadrangula. Aquaculture 410-411:190-196. https://doi.org/10.1016/j.aquaculture.2013.06.026

49. Urrutia-Cordero P, Ekvall MK, Ratcovich J, et al (2017) Phytoplankton diversity loss along a gradient of future warming and brownification in freshwater mesocosms. Freshw Biol 62:1869-1878. https://doi.org/10.1111/fwb.13027

50. Vandekerkhove J, Declerck S, Brendonck L, et al (2005a) Hatching of cladoceran resting eggs: Temperature and photoperiod. Freshw Biol 50:96-104. https://doi.org/10.1111/j.13652427.2004.01312.x

51. Vandekerkhove J, Declerck S, Brendonck L, et al (2005b) Hatching of cladoceran resting eggs: Temperature and photoperiod. Freshw Biol 50:96-104. https://doi.org/10.1111/j.13652427.2004.01312.x

52. Vandekerkhove J, Niessen B, Declerck S, et al (2004) Hatching rate and hatching success with and without isolation of zooplankton resting stages. Hydrobiologia 526:235-241. https://doi.org/10.1023/B:HYDR.0000041598.68424.fc

53. Vigneault B, Percot A, Lafleur M, Campbell PGC (2000) Permeability changes in model and phytoplankton membranes in the presence of aquatic humic substances. Environ Sci Technol 34:3907-3913. https://doi.org/10.1021/es001087r

54. Warton DI, Lyons M, Stoklosa J, Ives AR (2016) Three points to consider when choosing a LM or GLM test for count data. Methods Ecol Evol 7:882-890. https://doi.org/10.1111/2041-210X.12552

55. Wêgleñska T, Ejsmontkarabin J, Rybak JI (1997) Biotic Interactions of the Zooplankton Community of a Shallow, Humic Lake. Hydrobiologia 342:185-195. https://doi.org/10.1007/978-94-011-56486_20

56. Weyhenmeyer GA, Karlsson J (2009) Nonlinear response of dissolved organic carbon concentrations in boreal lakes to increasing temperatures. Limnol Oceanogr 54:2513-2519. https://doi.org/10.4319/lo.2009.54.6_part_2.2513

57. Yan ND, Girard R, Heneberry JH, et al (2004) Recovery of copepod, but not cladoceran, zooplankton from severe and chronic effects of multiple stressors. Ecol Lett 7:452-460. https://doi.org/10.1111/j.1461-0248.2004.00599.x

\section{Figures}




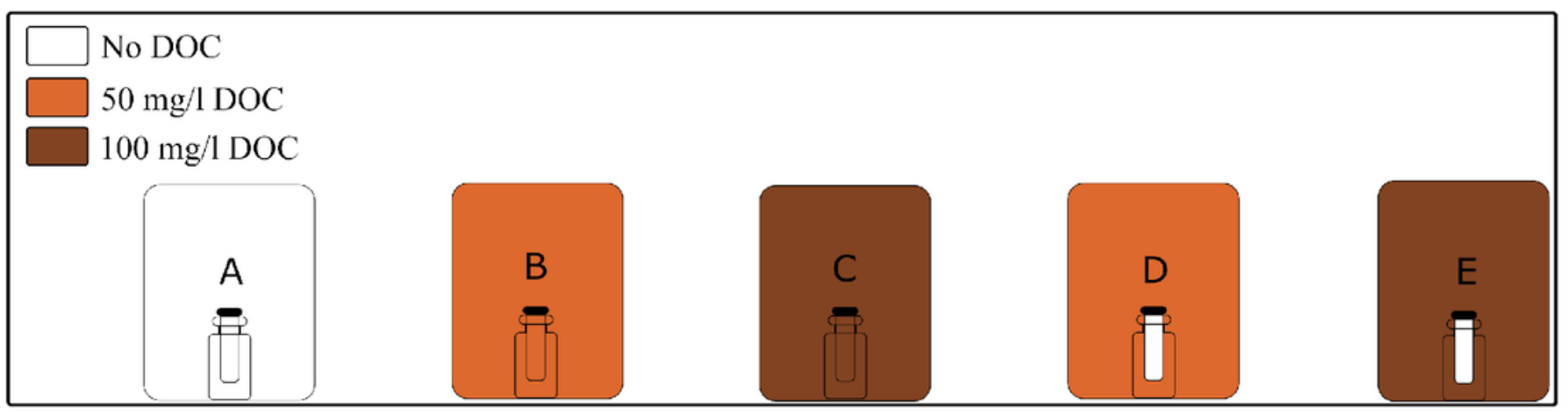

Figure 1

Experimental design for testing the chemical and physical effects of varying DOC concentrations $(0,50$ and $100 \mathrm{mg} / \mathrm{L} \mathrm{DOC}$ ) on hatching patterns of Diaphanosoma birgei resting eggs. Resting eggs were incubated in small flasks $(50 \mathrm{ml})$ that were placed inside big flasks $(500 \mathrm{ml})$ without exchanging water between them. Physical effects of DOC (i.e. light attenuation) were tested by incubating resting eggs in control water surrounded by DOC-enriched water (treatments $C$ and E). Chemical (i.e. toxic) plus physical effects of DOC were tested by incubating resting eggs in DOC-enriched water surrounded by water with the same DOC concentration (treatments B and D). Control treatments consisted of DOC-free water (treatment $A$ ). Chemical effects of DOC were inferred by comparing treatments with the same DOC concentration (treatments $\mathrm{B} \times \mathrm{C}$; and $\mathrm{D} \times \mathrm{E}$ ).

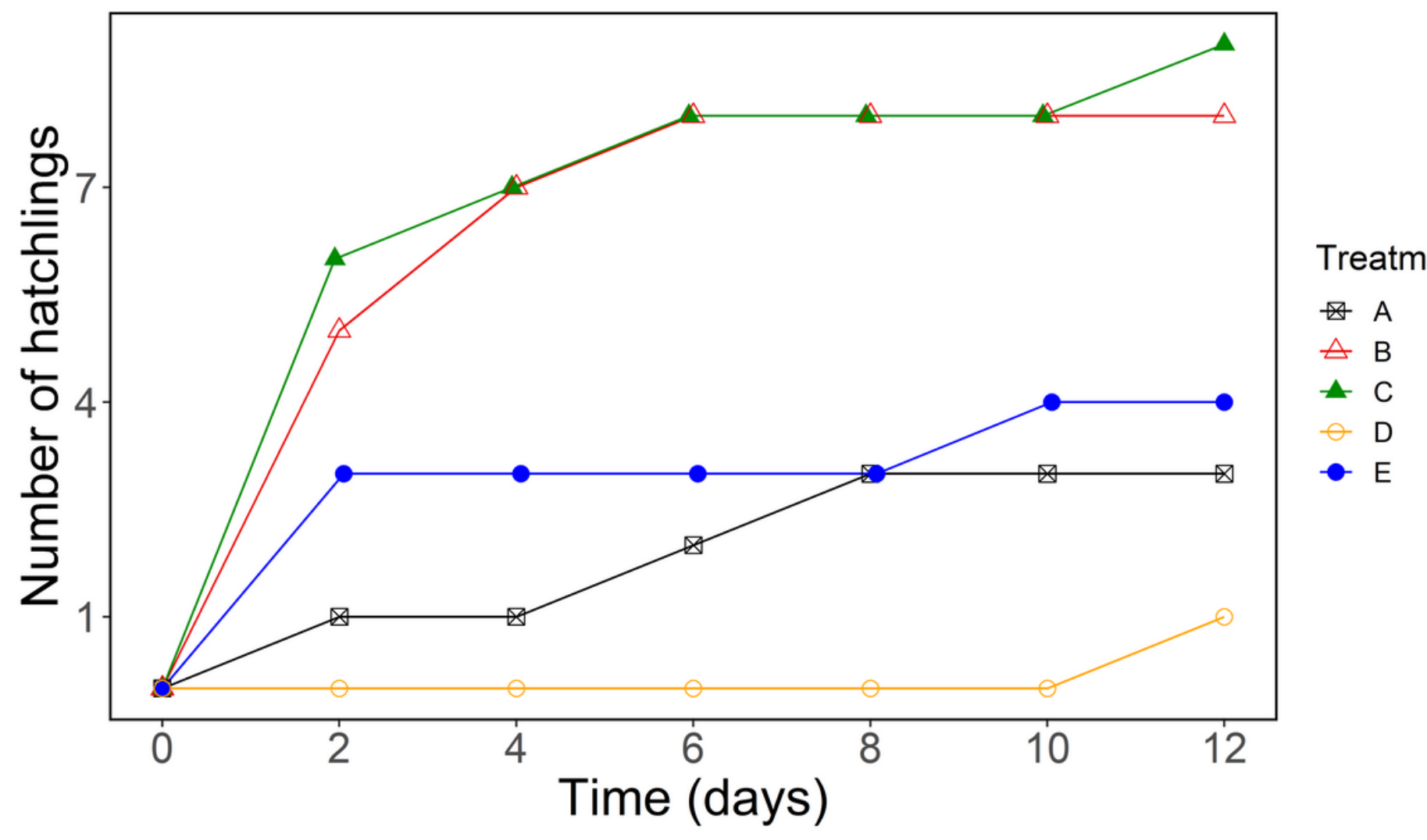

Figure 2 
Cumulative number of hatchlings over time. No hatchlings were observed after the 12th day of the experiment. Resting eggs were exposed to DOC-mediated changes in chemical and physical characteristics of water. Descriptions of treatments: A, Control; B, $50 \mathrm{mg} / \mathrm{L} \mathrm{DOC}$ chemical and physical effects; C, $50 \mathrm{mg} / \mathrm{L}$ DOC physical effects; D, $100 \mathrm{mg} / \mathrm{L}$ DOC chemical and physical effects; $E, 100 \mathrm{mg} / \mathrm{L}$ DOC physical effects.
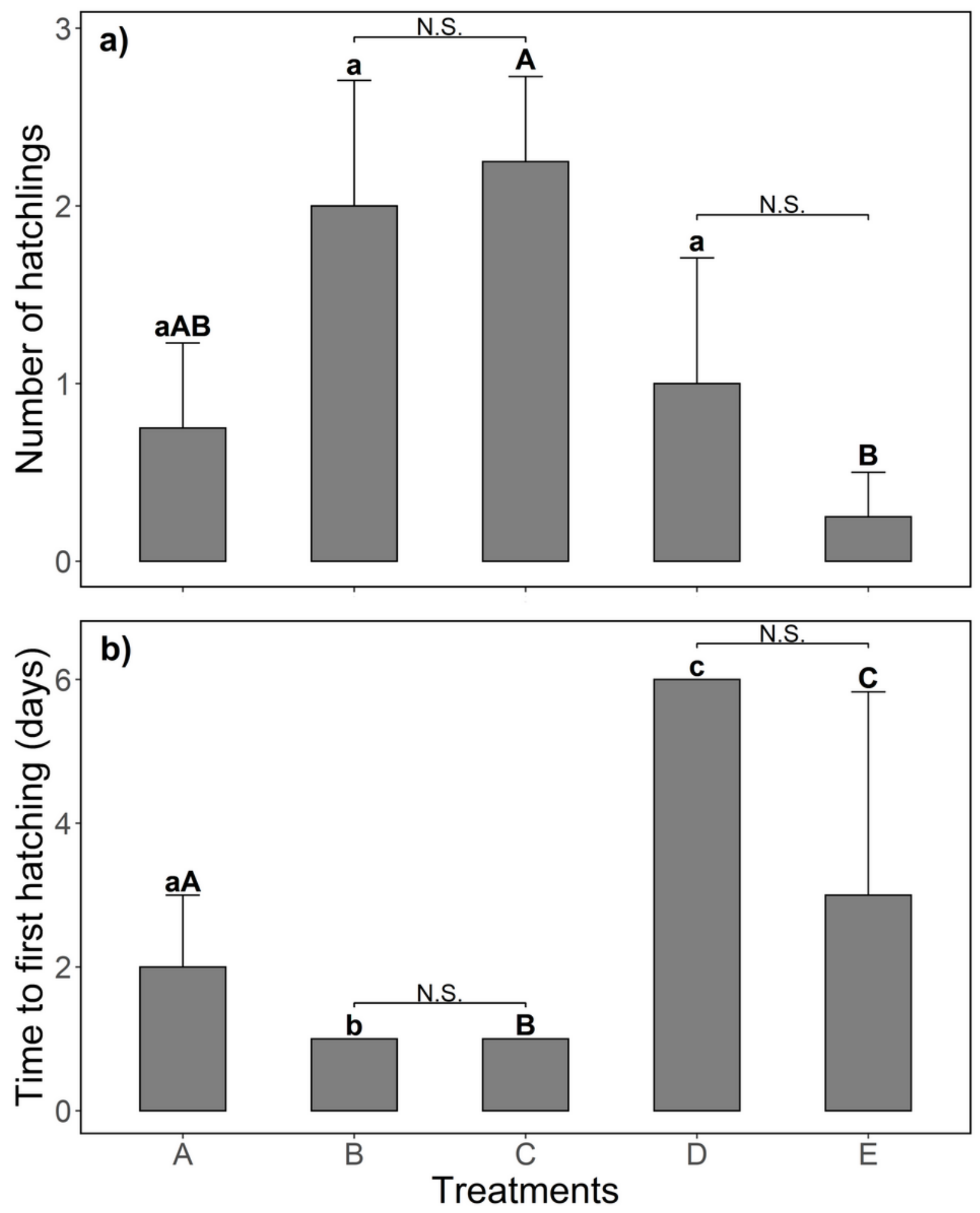

Figure 3 
Hatching responses (mean $+1 \mathrm{SE}$ ) of Diaphanosoma birgei resting eggs exposed to DOC-mediated changes in chemical and physical characteristics of water. (a) Number of eggs that hatched and (b) time to first hatching. Different letters above bars denote differences in treatments comparing "chemical + physical" effects (lowercase letters, treatments A, B and D) or "physical" effects only (uppercase letters, treatments $A, C$ and $E$ ). Horizontal lines denote comparisons of treatments with the same DOC concentrations. Descriptions of treatments: A, Control; B, 50mg/L DOC chemical and physical effects; C, $50 \mathrm{mg} / \mathrm{L}$ DOC physical effects; D, 100mg/L DOC chemical and physical effects; E, 100mg/L DOC physical effects. 